\title{
Perspective
}

\section{Sustaining the Arctic in Order to Sustain the Global Climate System}

\author{
Daniel Bodansky ${ }^{1, * \mathbb{D}}$ and Rafe Pomerance ${ }^{2}$ \\ 1 Sandra Day O'Connor College of Law, Arizona State University, Phoenix, AZ 85004, USA \\ 2 Woodwell Climate Research Center, Falmouth, MA 02540, USA; rafe.pomerance@gmail.com \\ * Correspondence: Daniel.Bodansky@asu.edu
}

Citation: Bodansky, D.; Pomerance, R. Sustaining the Arctic in Order to Sustain the Global Climate System. Sustainability 2021, 13, 10622. https:// doi.org/10.3390/su131910622

Academic Editors: Stephanie Pfirman, Gail Fondahl, Grete K. Hovelsrud and Tero Mustonen

Received: 18 July 2021

Accepted: 18 September 2021

Published: 24 September 2021

Publisher's Note: MDPI stays neutral with regard to jurisdictional claims in published maps and institutional affiliations.

Copyright: (c) 2021 by the authors. Licensee MDPI, Basel, Switzerland. This article is an open access article distributed under the terms and conditions of the Creative Commons Attribution (CC BY) license (https:/ / creativecommons.org/licenses/by/ $4.0 /)$.

\begin{abstract}
The unraveling of the Arctic is bad enough for the Arctic itself, but it will have enormous consequences for the entire planet since the Arctic is a crucial component of the global climate system. Current policies do not provide much hope to prevent these harms. We have committed the earth to too much warming to take a step-by-step approach. We have entered a period of history when planetary management has become unavoidable and must move forward on many fronts simultaneously. Key components of a multiprong approach include decarbonization, focus on shortlived climate forcers, greenhouse gas removal, adaptation, Arctic interventions, and solar climate intervention. This article discusses the last option, which may be the only means of cooling the earth quickly enough to save Arctic ice and permafrost. Scientific research is essential to better understand its feasibility, effectiveness, and safety. However, research is not enough; we need to be ready to respond right away if Arctic or global temperatures need to be lowered quickly. This means we need significant technology research and development so that solar climate intervention technologies are deployment-ready in the relatively near future, perhaps in a decade or two, and could be used should the need arise and should research show that they are effective and safe.
\end{abstract}

Keywords: Arctic; climate engineering; climate intervention; solar radiation management

The year 2021 has seen a number of welcome developments on the international climate change front - the reengagement by the United States in the Paris Agreement; the increasing number of pledges by countries to achieve net-zero emissions by mid-century or thereabouts; and the slew of climate change initiatives by investors, industry groups, and other non-state actors. But while these are all essential steps forward in international climate policy, will they be enough to keep the Arctic from unraveling and causing dire harm to the global climate system? We think not and therefore propose a multiprong strategy to sustain the Arctic, including the possibility of solar climate interventions, if shown to be safe and effective.

Each week seems to bring more bad news:

- Arctic sea ice thinned $60 \%$ more than previous estimates in the period from 2002 to 2018 [1].

- Warm water from the North Atlantic is hindering sea-ice growth in the Arctic Ocean [2].

- Melting at the bottom of the ice sheet (not just surface melting) accounts for a significant amount of Greenland ice loss [3].

- The majority of marine-terminating glaciers in northwest and central-west Greenland are experiencing accelerating mass loss [4].

- Temperatures in the Russian Arctic exceeded $30{ }^{\circ} \mathrm{C}$ in May, more than $20^{\circ} \mathrm{C}$ above average for that time of year, accelerating the collapse of Russian infrastructure from thawing permafrost [5].

In a powerful message, a recent report by the Arctic Monitoring and Assessment Program (AMAP) found that the Arctic has warmed three times as much as the global 
average over the last fifty years, not two or two-and-a-half times as much as previously believed [6]. One study found that we may be nearing the threshold beyond which Greenland ice loss will be irreversible [7].

The unraveling of the Arctic is bad enough for the Arctic itself, but it will have enormous consequences for the entire planet since the Arctic is a crucial component of the global climate system [8]. Its sea ice and spring snow cover reflect an enormous amount of heat back into space, its frozen high-latitude soils contain double the carbon content of the atmosphere [9], and its glacial ice holds enough water to cause over seven meters of sea-level rise [10].

Given its central role in the climate system, "what happens in the Arctic does not stay in the Arctic," as an Arctic official once put it [11]. As Arctic ice melts and spring snow cover shrinks, the Arctic Ocean and land surface become darker and reflect less sunlight back into space, thereby exacerbating global warming [12]. As Arctic permafrost thaws, it releases carbon dioxide and methane, potentially using up much, if not all, of the greenhouse gas budget available to limit global warming to $1.5^{\circ} \mathrm{C}$, according to recent estimates [13]. As Greenland and other smaller Arctic glaciers melt, sea-level rise accelerates, tying the fate of Greenland to the fate of Miami. As the Arctic atmosphere warms, the jet stream likely weakens, radically altering mid-latitude weather patterns, as we are witnessing in real time [14].

Can these harms be prevented? Current policies do not provide much hope.

- $1.5^{\circ} \mathrm{C}$ temperature goal-Global climate policy, as reflected in the Paris Agreement, aims to limit global warning to $1.5^{\circ} \mathrm{C}$ at best. However, as the IPCC $1.5^{\circ} \mathrm{C}$ Special Report indicates, even if we were able to limit global warming to $1.5^{\circ} \mathrm{C}$, there would still be significant harms [15]. Already, the Great Barrier Reef and most of the world's other coral reefs are dead or dying, and the world is experiencing more extreme weather events, including worsening droughts and wildfires, greater heat extremes, and more intense tropical storms. Additionally, global warming of $1.5^{\circ} \mathrm{C}$ means Arctic warming of about $4.5^{\circ} \mathrm{C}$. Moreover, that is the best-case scenario. Limiting warming to $1.5^{\circ} \mathrm{C}$ would be huge stretch, given the continuing upward trend in global greenhouse gas emissions and the fact that the atmosphere already contains $419 \mathrm{ppm}$ of $\mathrm{CO}_{2}, 50 \%$ percent above pre-industrial levels. In reality, we will be lucky to limit global warming to $2{ }^{\circ} \mathrm{C}$, a temperature increase that the paleoclimate record suggests would ultimately be accompanied by many meters of sea-level rise [16]. The world could easily be on its way to a warming of $3{ }^{\circ} \mathrm{C}$, which would mean $9^{\circ} \mathrm{C}$ of Arctic warming, if the Arctic continues to warm three times faster than the global average.

- Emissions pathways: overshoot and return-Most of the emission pathways considered by the IPCC to achieve the $1.5^{\circ} \mathrm{C}$ target assume that we will initially overshoot the target and then need negative emissions to bring temperature back down. The problem is that some of the harm from overshoot will be effectively irreversible in meaningful time frames, such as the release of carbon dioxide and methane from thawing permafrost and the disappearance of Greenland and other Arctic-as well as Antarctic and mid-latitude-glaciers.

- Arctic policy-Arctic policymaking appears even less promising. The Arctic Council, the principal Arctic-specific governance body, is an informal institution that lacks any regulatory powers and shows no signs of being up to the task of taking significant action. Despite the release of the 2021 Arctic assessment report showing that the Arctic is warming three times faster than the global average, the Arctic Council has not even called worldwide attention to the critical role the Arctic plays for the rest of the world. It has failed to establish a tolerable upper bound for climate change in the Arctic or to answer the question, "What is the Arctic we have to have to sustain the global climate system?" Instead, at its most recent meeting, it merely "not[ed] with concern the serious threats to Arctic ecosystems due to climate change" and "reiterate[d] the need for enhanced action to meet the long-term temperature goal and effective implementation of the Paris Agreement [17]." 
What is to be done? There are no perfect options. We have committed the earth to too much warming to take a step-by-step approach. We must realize that we have entered a period of history when planetary management has become unavoidable and move forward on many fronts simultaneously. Key components of a multiprong approach include

1. Decarbonization-First and foremost, the world needs to very rapidly decarbonize, as the Paris Agreement suggests. Even if emission reductions are unlikely to take effect quickly enough to completely preserve Arctic ice and permafrost, they are essential in the long run to stabilizing the global climate system. This is climate policy's most urgent task.

2. Short-Lived Climate Forcers (SLCFs)—Second, we need to halt emissions of SLCFs, such as methane and black carbon, which are particularly potent contributors to climate change [18].

3. Greenhouse gas removal-Third, we need to intensify efforts to remove carbon dioxide and other greenhouse gases from the atmosphere through nature-based and/or technological means (for example, afforestation, soil carbon sequestration, enhanced terrestrial weathering, mineral carbonation, or direct air capture).

4. Adaptation-Fourth, to the extent possible, we need to take measures to help the Arctic adapt to the effects of climate change.

5. Arctic interventions-Fifth, we need to explore proposals for saving Arctic ice through local interventions to limit summer melt, enhance winter freezing, or stabilize Greenland glaciers.

6. Solar climate intervention (SCI)—Sixth, we need to explore the possibility of using technology to reflect more sunlight away from the earth in order to cool it rapidly.

The first four approaches have been written about extensively, are well accepted internationally, and need little defense. By contrast, the last two approaches have received much less attention. One of us has written recently about Arctic interventions [19], so we focus here on the last option, using technology to reflect more sunlight-also referred to as solar climate engineering or solar radiation management (SRM). Solar climate intervention is perhaps the most controversial proposal to address climate change but may be the only means of cooling the earth quickly enough to save the Arctic. Potentially, it could be used to eliminate overshoot on the way to achieving the $1.5^{\circ} \mathrm{C}$ Paris target-a huge environmental benefit. Indeed, solar climate intervention could actually lower warming below $1.5^{\circ} \mathrm{C}$, perhaps reaching the equivalent of radiative forcing of $350 \mathrm{ppm}$ of $\mathrm{CO}_{2}$.

Various techniques to reflect sunlight have been suggested. These include injecting aerosols into the stratosphere to scatter incoming sunlight (stratospheric aerosol injection or SAI) and spraying sea salt from ships to provide cloud condensation nuclei and thereby brighten marine clouds (marine cloud brightening or MCB).

Volcanic eruptions provide proof-of-concept that stratospheric aerosols cool the planet. The sulfur aerosols injected into the stratosphere by the eruption of Mount Pinatubo in 1991 cooled the planet by about $0.5^{\circ} \mathrm{C}$. Hence, we dub using solar climate intervention to cool the planet by $1.0{ }^{\circ} \mathrm{C}$ a "Two Pinatubo" strategy. Recent modeling suggests that injecting aerosols into the stratosphere in the spring near the Arctic could restore significant amounts of Arctic sea ice and substantially reduce both local and global impacts of climate change [20].

A Two Pinatubo strategy raises many questions. For example,

- How would solar climate interventions affect the Arctic climate, as well as other regional climates and the global climate system?

- What are the advantages and disadvantages of stratospheric aerosol injection in the Arctic as compared to marine cloud brightening, taking into consideration technical feasibility, ability to scale up quickly, effectiveness in reducing temperature, and safety?

- If stratospheric aerosol injection were being considered, which aerosols should be used, how should they be lofted into the stratosphere and dispersed, and at what location(s) and altitude?

- What are the risks of solar climate intervention? What are the benefits? 
- How should SCI be governed, either nationally and/or internationally? Who should make decisions and how? What safety, environmental, and other requirements would need to be met before an intervention should be allowed to proceed?

Thus far, insufficient research has been done on solar climate intervention, so we still know too little about its feasibility, effectiveness, and safety. In response, there have been growing calls to develop a research program on solar climate intervention, most recently in a report of the National Academy of Sciences [21].

We strongly support an immediate and focused research program, exploring all potential options to address the Arctic crisis. Given the gravity of the threat and the dwindling time to respond, we believe solar climate intervention research, in particular, warrants considerably higher funding than the modest amounts recommended by the National Academy of Sciences report (\$100-200 million over five years).

Scientific research is not enough, however. Given the urgency of the Arctic crisis, we need to be ready to respond right away if Arctic or global temperatures need to be lowered quickly. This means we need significant technology research and development so that solar climate intervention is deployment-ready in the relatively near future, perhaps in a decade or two.

In saying that SCI should be deployment-ready in a decade or two, we want to be absolutely clear: we are not advocating its deployment. Whether it makes sense to deploy SCI will depend on what research shows about its effectiveness and safety. The response to COVID-19 provides a useful analogue. The goal of Operation Warp Speed was to develop deployment-ready vaccines, but the decision to go ahead with Warp Speed did not prejudge whether any of the vaccines that were developed should actually be used. Decisions about use depended on what the clinical trials showed about a vaccine's effectiveness and safety.

When one is dealing with a crisis, one cannot afford to proceed in an incremental, stepwise manner. That is why, if we are to have any chance of saving the Arctic the world needs, we cannot afford to do basic research first and only start developing deployable technologies later, as the NAS report suggests. We need to proceed on all fronts simultaneously. We need to develop the necessary technologies now so that we are ready to deploy them at scale, should the need arise and should the research show that they are safe.

Author Contributions: Conceptualization, writing, review and editing: D.B. and R.P. Both authors have read and agreed to the published version of the manuscript.

Funding: This research received no external funding.

Institutional Review Board Statement: Not applicable.

Informed Consent Statement: Not applicable.

Data Availability Statement: Not applicable.

Conflicts of Interest: The authors declare no conflict of interest.

\section{References}

1. Mallett, R.D.C.; Stroeve, J.C.; Tsamados, M.; Landy, J.C.; Willatt, R.; Nandan, V.; Liston, G.E. Faster decline and higher variability in the sea ice thickness of the marginal Arctic seas when accounting for dynamic snow cover. Cryosphere 2021, 15, 2429-2450. [CrossRef]

2. Ricker, R.; Kauker, F.; Schweiger, A.; Hendricks, S.; Zhang, J.; Paul, S. Evidence for an increasing role of ocean heat in Arctic winter sea ice growth. J. Clim. 2021, 34, 5215-5227.

3. Karlsson, N.B.; Solgaard, A.M.; Mankoff, K.D.; Gillet-Chaulet, F.; MacGregor, J.A.; Box, J.E.; Citterio, M.; Colgan, W.T.; Larsen, S.H.; Kjeldsen, K.K.; et al. A first constraint on basal melt-water production of the Greenland ice sheet. Nat. Commun. 2021, $12,3461$. [CrossRef]

4. Black, T.E.; Joughin, I. Multi-Decadal Retreat of Marine-Terminating Outlet Glaciers in Northwest and Central-West Greenland. The Cryosphere 2021. Available online: https:/ / doi.org/10.5194/tc-2021-164 (accessed on 10 September 2021).

5. Staalesen, A. The looming Arctic collapse: More than $40 \%$ of north Russian buildings are starting to crumble. Arctic Today 2021. Available online: https://www.arctictoday.com/the-looming-arctic-collapse-more-than-40-of-north-russian-buildingsare-starting-to-crumble/ (accessed on 10 September 2021). 
6. Arctic Monitoring and Assessment Programme (AMAP). Arctic Climate Change Update 2021: Key Trends and Impacts; AMAP: Tromsø, Norway, 2021.

7. Boers, N.; Rypdal, M. Critical slowing down suggests that the western Greenland Ice Sheet is close to a tipping point. Proc. Natl. Acad. Sci. USA 2021, 118, e2024192118. [CrossRef] [PubMed]

8. Moon, T.A.; Overeem, I.; Druckenmiller, M.; Holland, M.; Huntington, H.; Kling, G.; Lovecraft, A.L.; Miller, G.; Scambos, T.; Schädel, C.; et al. The expanding footprint of rapid Arctic change. Earth's Future 2019, 7, 212-218. [CrossRef]

9. Tarnocai, C.; Canadell, J.G.; Schuur, E.A.G.; Kuhry, P.; Mazhitova, G.; Zimov, S. Soil organic carbon pools in the northern circumpolar permafrost region. Glob. Biogeochem. Cycles 2009, 23, GB2023. (estimating northern circumpolar permafrost region contains $1672 \mathrm{Pg}$ of organic carbon, compared to $750 \mathrm{PgC}$ in the at-mosph ere). [CrossRef]

10. Aschwanden, A.; Fahnestock, M.A.; Truffer, M.; Brinkerhoff, D.J.; Hock, R.; Khroulev, C.; Mottram, R.; Khan, S.A. Contribution of the Greenland Ice Sheet to sea level over the next millennium. Sci. Adv. 2019, 5, eaav9396. [CrossRef]

11. 'What Happens in the Arctic, Does Not Stay in the Arctic'-Climate Change in the Arctic Will Have Global Consequences and Cannot Be Ignored. NATO Parliamentary Assembly News. 17 May 2017. Available online: https:/ /www.nato-pa.int/news/whathappens-arctic-does-not-stay-arctic-climate-change-arctic-will-have-global-consequences (accessed on 10 September 2021).

12. Pistone, K.; Eisenman, I.; Ramanathan, V. Radiative heating of an ice-free Arctic Ocean. Geophys. Res. Lett. 2019, 46, 7474-7480. (estimate that an ice-free Arctic Ocean would result in radiative forcing of $0.71 \mathrm{~W} / \mathrm{m}^{2}$, the equivalent of one trillion tons of $\mathrm{CO}_{2}$ emissions, speeding global warming by an estimated 25 years). [CrossRef]

13. Natali, S.M.; Holdren, J.P.; Rogers, B.M.; Treharne, R.; Duffy, P.B.; Pomerance, R.; MacDonald, E. Permafrost carbon feedbacks threaten global climate goals. Proc. Natl. Acad. Sci. USA 2021, 118, e2100163118. (estimating e missions from permafrost thaw of up to $550 \mathrm{Gt}$ of $\mathrm{CO}_{2}$ by 2100 , assuming weak climate policies, com-pared to a carbon budget of 340-1000 $\mathrm{Gt}_{\text {t }} \mathrm{CO}_{2}$-e for a likely chance of remaining below $2{ }^{\circ} \mathrm{C}$ and a budget of $290-440 \mathrm{Gt}$ to remain below $1.5^{\circ} \mathrm{C}$ ). [CrossRef]

14. Overland, J.E.; Wang, M. Resolving future Arctic/midlatitude weather connections. Earth's Future 2018, 6, 1146-1152. [CrossRef]

15. Intergovernmental Panel on Climate Change. Global Warming of $1.5{ }^{\circ} \mathrm{C}$ : An IPCC Special Report. 2018. Available online: https://www.ipcc.ch/sr15/ (accessed on 10 September 2021).

16. Hansen, J.; Sato, M.; Hearty, P.; Ruedy, R.; Kelley, M.; Masson-Delmotte, V.; Russell, G.; Tselioudis, G.; Cao, J.; Rignot, E.; et al. Ice melt, sea level rise, and superstorms: Evidence from paleoclimate data, climate modeling, and modern observations that $2{ }^{\circ} \mathrm{C}$ global warming could be dangerous. Atmos. Chem. Phys. 2016, 16, 3761-3812. [CrossRef]

17. 12th Arctic Council Ministerial Meeting, Reykjavík Declaration 2021, preambular 8, para. 19. Available online: https:/ / oaarchive. arctic-council.org/bitstream/handle/11374/2600/declaration\%202021\%20web\%20EN.pdf?sequence=9\&isAllowed=y (accessed on 10 September 2021).

18. Arctic Council. Expert Group on Black Carbon and Methane-3rd Summary of Progress and Recommendations; Arctic Council: Tromsø, Norway, 2021.

19. Bodansky, D.; Hunt, H. Arctic Climate Interventions. Int. J. Mar. Coast. Law 2020, 35, 596-617. [CrossRef]

20. Lee, W.R.; MacMartin, D.G.; Visioni, D.; Kravitz, B. High-latitude stratospheric aerosol geoengineering can be more effective if injection is limited to spring. Geophys. Res. Lett. 2021, 48, e2021GL092696. [CrossRef]

21. National Academies of Sciences, Engineering and Medicine. Reflecting Sunlight: Recommendations for Solar Geoengineering Research and Research Governance; National Academies Press: Washington, DC, USA, 2021. 